\title{
What does morality require when we disagree?
}

\section{Andersen, Martin Marchman}

\section{Published in:}

Journal of Moral Philosophy

Link to article, DOI:

10.1163/17455243-20170001

Publication date:

2019

Document Version

Peer reviewed version

Link back to DTU Orbit

Citation (APA):

Andersen, M. M. (2019). What does morality require when we disagree? Journal of Moral Philosophy, 16(1). https://doi.org/10.1163/17455243-20170001

\section{General rights}

Copyright and moral rights for the publications made accessible in the public portal are retained by the authors and/or other copyright owners and it is a condition of accessing publications that users recognise and abide by the legal requirements associated with these rights.

- Users may download and print one copy of any publication from the public portal for the purpose of private study or research.

- You may not further distribute the material or use it for any profit-making activity or commercial gain

- You may freely distribute the URL identifying the publication in the public portal

If you believe that this document breaches copyright please contact us providing details, and we will remove access to the work immediately and investigate your claim. 


\title{
What does morality require when we disagree?
}

(A version of this paper is published in Journal of Moral Philosophy)

\begin{abstract}
In "Principled Compromise and the Abortion Controversy" Simon C. May argues that we do not have a principled moral reason to compromise. While I seek to understand how more precisely we are to understand this suggestion, I also object to it: I argue that we have a principled moral reason to accept democratic decisions that we disagree with, and that this can only be so if disagreement can change what the all things considered right political position is. But if this is so, then also a principled moral reason to compromise is possible. I suggest that there is a class of procedures, including compromise, voting, expert delegation, and coin flip, such that when we disagree about what justice requires, we have a principled moral reason (though not necessarily a decisive reason) to engage in one of these procedures.
\end{abstract}

\section{Keywords}

Compromise

Democracy

Disagreement

Legitimacy

\section{Manuscript}

Suppose you are the sovereign king of a country of 5 million people and have the financial and military power to implement whatever policy you like. Suppose justice as fairness, as laid out by Rawls, is what justice requires, and suppose you know that and govern your country accordingly because you want to do what justice requires. One day, however, you become curious about the people's take on justice, and therefore you make up a "democracy for fun": You ask the people to vote on whatever general principles of justice they would follow if they were in your position. They all vote, and they all vote for a society guided by the minimal 
principles put forward by Robert Nozick in Anarchy, State, and Utopia.

Now, given this information, should you continue to govern the country in accordance with justice as fairness, paying no attention to the fact that the people disagree, or should you somehow compromise with the people and let their view on what justice requires, even though wrong, be reflected in the policies you implement? Since you already know what justice requires, ex hypothesi, you have no epistemic reason to compromise. Neither do you have pragmatic moral reasons to compromise, say wishes for peace and stability, since you have all the military power. You are, ex hypothesi, the sovereign king! If you have a reason to compromise, it therefore seems to be a principled moral reason, and, following Simon C. May, you have a principled moral reason to compromise only if the mere fact of disagreement somehow "gives rise to a reason for compromise in itself, aside from any impediment to other goals it may incidentally generate". ${ }^{1}$ But do you have such a reason? This question seems important since persistent disagreement is a fundamental feature of human civilization, and we therefore need to know what our moral duties are when we disagree.

\section{1: Introduction}

In his 2005 paper "Principled Compromise and the Abortion Controversy" Simon C. May argues that neither reasons of moral complexity, respect, accommodation or reciprocity qualifies, respectively, as a principled moral reason to compromise. He therefore concludes that there is no principled moral reason to compromise, that "(...) compromise in political life is only ever warranted for pragmatic reasons." I believe this suggestion is both interesting and important $^{2}$, but, nonetheless, also inaccurate or mistaken.

\footnotetext{
${ }^{1}$ Simon C. May, 'Principled Compromise and the Abortion Controversy', Philosophy and Public affairs 33 (2005), pp. 317-348, p. 320.

2 Not least because quite a few scholars seem to think we do have principled reason to compromise, for instance: Patrick Dobel, Compromise and Political Action: Political Morality in Liberal and Democratic Life (Maryland:
} 
This is so because there is a close connection between our (lack of) principled moral reason to compromise and our (lack of) principled moral reason to accept a democratic decision that we disagree with. In order to show that there is no principled moral reason to compromise, May rejects the possibility that the mere fact of disagreement is "[...] a reason to accept a political position otherwise perceived to be morally inferior". ${ }^{3}$ But thereby he also rules out the possibility that there is principled (non-instrumental) moral reason for democracy. But, as I will argue, we do have a principled moral reason for democracy. The mere fact of disagreement is a reason to accept a political position otherwise perceived to be morally inferior. Or, as I will fraise it later, disagreement can change what the all things considered right political position is, and therefore there can also be a principled moral reason to compromise.

The aim of the paper is twofold. The first aim is to examine May's argument and show that his conclusion implies that there can be only instrumental reasons for democracy, if any. On the contrary, if democracy has a non-instrumental justification, there can also be a principled moral reason to compromise. The second aim is to benefit from the conceptual framework of that examination in order to shed light on the more general question of what morality requires when we disagree. There is no reason to think that the nature of compromises is detached from the nature of democracy. By examining our reasons for democracy, we can learn about our reasons (not) to compromise. By examining both we can come to learn more generally about our moral obligations when we disagree.

Savage, Rowman and Littlefield, 1990), p. 80; Joseph Carens, 'Compromise in Politics', in eds. R. Pennoch and J. Chapman, Nomos XXI: Compromise in Ethics, Law, and Politics (New York: New York University Press, 1979), pp. 123-42, p. 135; Colin Bird, 'Mutual Respect and Neutral Justification', Ethics 107 (1997), pp. 62-96, p. 92; Stephen Macedo, 'Liberal Virtues: Citizenship, Virtue, and Community' in Liberal Constitutionalism (Oxford: Clarendon Press, 1990), p. 71; David Wong, 'Coping with Moral Conflict and Ambiguity', Ethics 102 (1992), pp. 763-784, p. 779; Fabian Wendt, Compromise, Peace and Public Justification: Political Reality beyond Justice (Palgrave, 2016); Richard Bellamy and Martin Hollis, 'Consensus, Neutrality and Compromise', in eds. R. Bellamy and M. Hollis, Pluralism and Liberal Neutrality, (London: Frank Cass \& Co., 1999), pp. 54-79.

${ }^{3}$ May, 'Principled Compromise and the Abortion Controversy', p. 318. 


\section{Overview of the paper}

Accordingly, in the next section of the paper, section 2, I present May's argument as I think we should understand it as for why there is no principled moral reason to compromise. Given potential ambiguities in some of the concepts involved, this presentation is detailed, and I will end up modifying some of it in order to make it easier to understand. (At least, that is my intention). In section 3, I will argue that there is a principled moral reason for democracy, and that this can only be so if disagreement can change what the all things considered right political position is. But if disagreement can change what the all things considered right political position is, then also a principled moral reason to compromise is possible. In the final section of the paper, section 4, I suggest, as a general answer as to what morality requires when we disagree, that there is a class of procedures, Px, including e.g. compromise, voting, expert delegation, lottery and coin flip, such that when we disagree about what justice requires, we have a principled moral reason (though not necessarily a decisive reason) to engage in one of the procedures in Px.

I should stress that I take justice to be a subcategory of morality. What justice requires is necessarily also required my morality, but morality may require more than justice. I also take it to be morality, not justice, that may or may not require something only because we disagree. ${ }^{4}$ Obviously, this specific way of framing it is not essential, but, to avoid misunderstandings, one way of framing it is preferable.

Thus, let me begin by presenting the details of May's argument.

\footnotetext{
4 Thereby I think I somehow follow Waldron who distinguishes between two tasks of political philosophy, namely theorizing about justice and theorizing about politics, such that matters of disagreement fall under the latter. See: Jeremy Waldron, Law and Disagreement (Oxford University Press, 1999), p. 3.
} 


\section{2: The argument against a principled moral reason to compromise}

According to May, a compromise occurs "[...] when disagreement is invoked as a reason to accept a political position otherwise perceived to be morally inferior". ${ }^{5}$ As there obviously is more to what a compromise exactly is, this is a necessary, not a sufficient, condition. Thus, for there to be a compromise it is a necessary condition that disagreement is a reason to accept an otherwise perceived morally inferior position.

Obviously, wishes for peace and wishes for political stability can generate reason to compromise. In such cases, however, the reason to accept an otherwise perceived morally inferior position is not the mere fact of disagreement. Rather, the reason stems from considerations about what will happen if the disagreement is persistent - what will happen if no compromise is reached. The reason is therefore a pragmatic moral reason to compromise, and no one seems to deny that we have such pragmatic moral reason to compromise.

The question of interest is therefore whether we have a principled moral reason to compromise. We have a principled moral reason to compromise only if the mere fact of disagreement "[...] gives rise to a reason for compromise in itself, aside from any impediment to other goals it may incidentally generate." ${ }^{6}$ In other words, if there is a moral reason to compromise only because there is disagreement, then that reason is a principled moral reason to compromise. This leads to the first premise in what I take to be May's argument against a principled moral reason to compromise:

\footnotetext{
${ }^{5}$ May, 'Principled Compromise and the Abortion Controversy', p. 318.

${ }^{6}$ May, 'Principled Compromise and the Abortion Controversy', p. 320.
} 
A) There is a principled moral reason to compromise, only if the mere fact of disagreement is a principled moral reason to accept a political position that we otherwise perceive to be morally inferior.

As a case of illustration, May asks us to consider a politician, Jane, "[...] who endorses a position that is, in actual fact, the best balancing of values and interests on an issue (although perhaps only after a long period of philosophical reflection, practical experience, and political deliberation)." 7 The question is then:

[...] even if Jane were in a position to successfully implement her political position in its entirety, say after leading her party to a decisive electoral victory (would she) still have principled reason for moral compromise with the dissenting minority independent of any pragmatic consideration of future political fallout [?]. ${ }^{8}$

To get a first glance of what a principled moral reason to compromise pertains to, this is a fine illustration. But it is also potentially misleading:

Jane being a politician "[...] leading her party to a decisive electoral victory" makes us think about the question of a principled compromise in a context where vital requirements of democracy, such as voting, are already satisfied. It seems plausible that at least some of us would think she should not compromise, exactly because there has already been a vote. But at the most basic level both compromise and voting seem to be members of a class of procedures that deals with disagreement (where some other members of this class are expert delegation

\footnotetext{
${ }^{7}$ May, 'Principled Compromise and the Abortion Controversy', p. 319.

8 May, 'Principled Compromise and the Abortion Controversy', p. 320-321.
} 
and coin flip). Once one procedure has been followed it seems to be some kind of double counting to follow yet another. Suppose two parties disagree and reach a compromise. Should they then also vote? Obviously not, but this does not show that there are never reasons to vote. Similarly, if two parties vote we would not think they should also compromise, but that would not imply that there are never reasons to compromise. If we want to know more fundamentally what our moral duties are when we disagree, we cannot yet assume any democratic context, whatever that more precisely involves. ${ }^{9}$ Therefore, here is a more back to basics case of illustration, call it the deserted island case:

\section{New case of illustration}

Imagine that (only) Ann and Ben constitute a community on a deserted island. They meet to decide collectively which fishing strategy and distributional policy to aim for. Ann is much stronger, and more intelligent than Ben. Ben can do some fishing, but he is weak, soon about to die, and his gain from fishing depends entirely on collaboration with Ann, whereas Ann is able to catch some fish on her own. Ann and Ben soon agree on the fishing strategy, but after both individual and joint philosophical deliberation they end up in persistent disagreement about what the just distribution of fish would be. Ben believes in policy P1: They should split the gain 50/50, whereas Ann believes in policy P2: The first two fish they catch each day should be split 50/50, but anything beyond that should be split 70/30 in her favour. Because Ben is weak, Ann has the power to say 'it is my way or the highway'. If she says so, Ben will give in, and they both know that. Now the question is: Does Ann have a reason to compromise with Ben?

\footnotetext{
${ }^{9} \mathrm{Or}$, as Daniel Weinstock has asked in a critic of May's suggestion, what if the democratic decision procedures are imperfect? Daniel Weinstock, 'On the possibility of principled moral compromise', Critical Review of International Social and Political Philosophy 16(2013), pp. 537-556, p. 549.
} 
In this case there is no pre-established societal decision-procedure to deal with disagreement. Since Ann has the power to implement the policy she otherwise perceives to be right, and since Ben is soon about to die, she does not seem to have any pragmatic moral reason to accept a division of fish that she otherwise perceives to be morally inferior. If she has a reason to accept an otherwise perceived inferior division, it therefore seems to be a principled moral reason. But does she have such a reason?

\section{Conceptual clarifications}

Having, hopefully, a better understanding of what a principled moral reason to compromise pertains to, recall that May's argument against a principled moral reason to compromise involves a rejection of the possibility that the mere fact of disagreement is a principled moral reason to accept an otherwise perceived morally inferior position. Following the deserted island case it is a rejection of the possibility that the mere fact that Ben disagrees with Ann gives Ann a reason to accept a division of fish that is inferior to the division she otherwise thinks is right. However, to understand exactly what this means we need to know, at least roughly, what counts as a reason, and we need to specify our use of the notion of otherwise.

First, I take it that a reason need not be decisive. For instance, you might have $a$ reason to compromise, but yet have reason not to compromise, all things considered. I take it that a reason counts as a reason only if it, either on its own, or in (non-redundant) conjunction with other reasons, can constitute decisive ground for (not) believing or (not) doing something. This seems pretty straightforward. However, relevant for our discussion is also the well- 
known debate about whether reasons are internal or external. ${ }^{10}$ May is not explicit about the matter, but I take the very question - do we have a principled moral reason to compromise? to presuppose an external reading of reason. This is so, because an internal reading of reason would make May's concluding proposition - that we do not have a principled moral reason to compromise - very easy to prove wrong. It would be wrong simply if there is a person included in the relevant "we" who actually believes she has a principled moral reason to compromise, and this is overwhelmingly likely to be the case. On fair and safe ground, I can therefore interpret May's proposition - that we do not have a principled moral reason to compromise - such that it would be wrong if it is true that morality requires principled compromise. If morality requires us to do something, we have a principled moral reason to do it.

Second: On the face of it, one might read the notion of otherwise to mean the following: When Ann accepts a political position that she otherwise perceives to be morally inferior, she accepts a political position that she all things considered perceives to be morally inferior to the political position she thinks is right. However, following what I took to count as a reason, I take it to be a conceptual truth that there can never be decisive reason to do anything that is inferior to the all things considered right thing to do. If a reason cannot be decisive, either on its own merits or in (non-redundant) conjunction with other reasons, it has no action guiding (or explanatory) power; it is not a reason for anything and does not deserve the name reason (or indeed any name). Therefore such reading of otherwise would be worth no discussion. I therefore take it that when Ann accepts a political position that she otherwise perceives to be

\footnotetext{
10 Bernard Williams, 'Internal and external reasons', in Moral Luck (Cambridge: Cambridge University Press, 1980), pp. 101-113.
} 
morally inferior, she accepts a political position that she, when she does not take the fact of disagreement into consideration, perceives to be morally inferior to the political position she thinks is right. Ben might offer Ann reasons to change her mind about what political position is otherwise right, and visa versa. ${ }^{11}$ But if Ann and Ben after such joint deliberation still disagree about what political position is otherwise right, the question is whether the fact that they disagree can change anything in regards to what political position they, respectively, should think is right all things considered, (and therefore eventually to compromise).

To illustrate, Ann perceives policy P2 to be the otherwise right policy. After having thought about it carefully, P2 is the policy she believes should be implemented. However, now Ben comes into the picture and disagrees that $\mathrm{P} 2$ is the right policy. The arguments that Ben brings in as for why P2 is not the right policy, are arguments that Ann has already considered and they did not make her change her mind about P2 being the otherwise right policy. Now the question is, does the mere fact that Ben disagrees that $\mathrm{P} 2$ is the right policy give Ann a reason (though not necessarily a decisive one) to change her mind about what policy is right, all things considered? Can the mere fact that Ben disagrees change the balance of reasons such that some compromise (of P1 and P2) is the all things considered right political position? Thus, the notion of otherwise simply operates by distinguishing between taking disagreement into consideration and not taking disagreement into consideration.

\section{The argument}

Having made it explicit what I take a reason to be and how we ought to interpret May's use of otherwise, I can now spell out what I take to be May's argument against a principled moral reason to compromise:

\footnotetext{
11 May, 'Principled Compromise and the Abortion Controversy', p. 318-319.
} 
A) There is a principled moral reason to compromise, only if the mere fact of disagreement is a principled moral reason to accept a political position that we otherwise perceive to be morally inferior.

B) Reasons of moral complexity, respect, accommodation and reciprocity do not imply that the mere fact of disagreement is a principled moral reason to accept a political position that we otherwise perceive to be morally inferior.

C) The mere fact of disagreement is no principled moral reason to accept a political position otherwise perceived to be morally inferior.

D) There is no principled moral reason to compromise.

Now, May goes from B to C by way of generalization:

The failure of these arguments means that there is no obvious reason why any sort of principled compromise on abortion should be sought. [...] I conclude by way of generalization of my arguments about the abortion controversy. If there is no principled reason to pursue a moral compromise on abortion, there are good grounds to believe that there is no reason to pursue a moral compromise on any political question. ${ }^{12}$

This generalization implies that even if B is correct it is still possible that the mere fact of disagreement is a principled moral reason to accept a political position otherwise perceived to be morally inferior, though, ex hypothesi, not because of moral complexity, respect, accommodation or reciprocity. In other words, these four candidates do not empty the space of possibilities for a principled reason to accept otherwise perceived inferior positions. Even

12 May, 'Principled Compromise and the Abortion Controversy', p. 318. 
though I will not object to May's rejections of these four candidates, at least not in any detailed way, the details of mainly the first one are, nonetheless, worth a few words:

\section{Moral complexity}

The suggestion that Ann has no principled moral reason to compromise with Ben is sensitive to an obvious objection: Ann might namely risk being wrong about her take on justice - about what the just division of fish actually is - and this risk of being mistaken might be more likely, ceteris paribus, because Ben disagrees with her. Generally, we seem to run the risk of being mistaken about what justice requires, and perhaps therefore the mere fact of disagreement can motivate why we (at least sometimes) should accept political positions that we otherwise perceive to be morally inferior?

According to May, however, such epistemic modesty is not conditional on the presence of disagreement. ${ }^{13}$ Even though justice is complex and we therefore risk being mistaken about what it requires, May argues that this fact of complexity does not give us a principled moral reason to compromise: If you cannot really know that your favoured policy is right, then neither can anyone else really know that their policy is right. Even if you are not sure that your policy is right, it is no principled reason to accept inferior political positions. As long as you believe your policy suggestion is (out of the available options) best supported by reasons, you have no reason to believe that a compromise policy (that is an otherwise inferior policy) would be better. ${ }^{14}$

\footnotetext{
13 See also Simon C. May, 'Compromise', in eds. H. LaFollette, International Encyclopedia of Ethics (Oxford: Blackwell, 2013), pp. 959-68.

14 May, 'Principled Compromise and the Abortion Controversy', p. 340.
} 
Whether or not (May's more detailed version of) this line of argument is sound, it calls for a division of the question we investigate. A principled moral reason to accept an otherwise inferior political position (and therefore eventually to compromise) might be an epistemic reason or a (pure) moral reason (or indeed both). To simplify the debate it is therefore helpful to split up premise A, the initial set up as for what it is May rejects.

A) There is a principled moral reason to compromise, only if the mere fact of disagreement is a principled moral reason to accept a political position that we otherwise perceive to be morally inferior.

There is a principled moral reason to compromise, only if

A1) the mere fact of disagreement is an epistemic reason to lower the credence in what we otherwise think is morally right.

Or:

A2) the mere fact of disagreement can change what the all things considered morally right political position is.

Thus, May rejects both A1 and A2. I will defend A2 and therefore focus mainly on that. If the mere fact of disagreement can change what the all things considered right political position is, then the mere fact of disagreement can be a principled moral reason to accept a political position that we otherwise perceive to be morally inferior, and then there can be principled moral reason to compromise.

\section{Respect, accommodation, and reciprocity}


May's three remaining candidates are potentially such (pure) moral reasons to think disagreement can change what the all things considered right political position is. In very rough terms, and without doing justice to the details of his arguments, May rejects them, because it is not clear what really bridges the gap between them and compromise. For instance, without further notice, we can be respectful and we can be accommodating without having to compromise. For instance, we can simply be respectful and listen to opposing views. ${ }^{15}$ However, in the next section I want to establish why (I think) disagreement can change what the all things considered right political position is. In doing so I do not presuppose that May is wrong in rejecting these three candidates. Let me therefore move on.

\section{3: Why disagreement can change the all things considered right political position}

In this section I will first give an intuitive case for thinking morality requires principled democracy. Second, I will establish what I mean by principled democracy, and third I will show why morality requires principled democracy only if disagreement can change the all things considered right political position. Fourth, I will explain more theoretically why I think morality requires principled democracy. In the final section of the paper I will elaborate on the relation between principled democracy and principled compromise.

Consider now an expanded version of my introductory case, call it the democracy for fun case:

Imagine you are the sovereign king of a country of 5 million people. You have the financial and military power to implement whatever policy you like. You are, however, also a man (or a woman) who wants to do what justice requires. You hire a team of expert advisors to help you think and plan your country in accordance with the requirements of justice. After a long

\footnotetext{
15 May, 'Principled Compromise and the Abortion Controversy', p. 343.
} 
deliberation you and your team come to the conclusion that your country should be guided by justice as fairness, as laid out by Rawls. Assume that this is what justice requires (or pick your own favoured theory of what justice requires). However, just as you have reached this conclusion, one of your advisors suggests that there may be epistemic reasons to listen to what the 5 million people have to say. They may give you reason to correct your view. Also, he suggests, there may be reasons of respect and accommodation to listen to what they have to say before you implement your policy. Curious about these suggestions you therefore decide to make up a "democracy for fun": You ask the people to vote on whatever general principles of justice they would follow if they were in your position. They all vote, and they all vote for a society guided by the minimal principles put forward by Robert Nozick in Anarchy, State, and Utopia (or something quite distant from what you have reason to believe justice requires).

Now, as the sovereign king you might listen to the people for reasons of moral complexity, respect, and accommodation, in May's understanding of these concepts, and yet make all the decisions yourself about which policies to implement. By listening to the people you show them respect, and you improve, at least potentially, the epistemic foundation of your policies when considering their arguments, and their preferences, which satisfy, respectively, the reason of moral complexity, and the reason of accommodation. But if disagreement is no principled moral reason to accept a political position that we otherwise perceive to be morally inferior, the fact that the entire population disagrees with you is no reason to adjust your policy. Still, not adjusting the policy seems wrong. Even though you, as the sovereign king, is otherwise right about the policy, ex hypothesi, there seems to be something intuitively wrong about implementing it. What can explain this intuition? 
Well, for a start we might wonder whether the intuition is epistemic. How can you be right if five million people disagree? Perhaps, as I spelled out above, the mere fact of disagreement is an epistemic reason to lower the credence in what you otherwise think is morally right. This, of course, might be so, and it might also be that deliberation and voting can be truth-tracking, such as suggested by for instance David Estlund. ${ }^{16}$ But as illustrated in the case, if there are such epistemic benefits in following such procedures, we can run them just for fun; we need not any official democratic constitution; we can use the people as advisors when we need their advises, but yet make all the decisions ourselves. Epistemic reasons, it seems, do therefore not explain the intuition that there is something wrong about implementing the otherwise right policy. So, what can explain it?

\section{Principled democracy}

It strikes me to be a very plausible (and indeed widespread) idea that democracy has more than pragmatic value. It strikes me to be plausible that we should honour democracy not only if it has certain epistemic qualities (e.g. Condorcet) or certain pragmatic moral implications, such as peace and stability, but also because we all ought to have a say, ceteris paribus, in the creation of decisions that affect us. I understand democracy as (at least) a set of procedures, such as deliberation and voting, as for how to make (collective) decisions in a society when we disagree about what justice requires. It strikes me to be very plausible that democracy, understood in this way, (also) has a principled value, and it has a principled value only if morality requires us to follow democratic procedures and accept their outcome independently of "[...] any impediment to other goals it may incidentally generate."17

\footnotetext{
16 David M. Estlund, Democratic Authority (Princeton University Press, 2008).

17 May, 'Principled Compromise and the Abortion Controversy', p. 320.
} 
Principled democracy so described seems to explain why it is wrong not to adjust your policy in the democracy for fun case. In fact, if morality requires principled democracy it gives you, as the sovereign king, one reason (though not necessarily a decisive reason) to abdicate and implement a democracy. But how more precisely should we understand this idea of principled democracy?

Well, at a political level I see three somewhat realistic views about what morality requires, if it requires anything. First, morality may require only justice. Morality may require that justice is brought about, for instance that justice as fairness, libertarianism, luck egalitarianism, utilitarianism, or what have you, is brought about; a specific distribution of relevant values (and criminal justice) to be brought about. Justice in that sense might simply be all that morality requires (at a political level). This implies that democracy is justified only if it tracks justice (instrumentalism). The problem with this view, however, is captured in the democracy for fun case: If you are on track with what justice requires, you have only pragmatic reasons, if any, to let opposing views have any impact (and even if opposing views are held by anyone but you).

Second, morality may require only (principled) democracy and not justice (at least not understood in any procedure-independent way). At a political level, what morality requires is democratic procedures, and what is right is determined by these procedures alone (proceduralism). ${ }^{18}$ The problem with this view, however, is that procedures are not substantial. If democratic procedures results in prosecution of some minority then prosecution of that minority is morally right.

\footnotetext{
${ }^{18}$ A more sophisticated version of this view is suggested by Vallentini. Under what she calls thick reasonable disagreement about justice, justice ceases to require anything procedure-independently and then democracy has instinsic value. See Laura Valentini, 'Justice, disagreement and democracy', British Journal of Political Science 43.01 (2013), pp. 177-199.
} 
Third, combining the first and the second view, morality requires justice as well as principled democracy. It requires a specific take on justice, namely the right one, to be realized, for instance justice as fairness. But it also requires principled democracy independently of justice: It requires that we follow democratic procedures and accept their outcome independently of any impediment to other goals it may incidentally generate, such as the goal of realizing justice.

\section{A paradox?}

This third view may seem paradoxically, such as Wollheim once has argued. ${ }^{19}$ Imagine there is an election between two mutually exclusive policies, A and B. Person P thinks of herself as a democrat. She believes policy A is right and therefore she votes for policy A. The next day, however, when all votes are counted, policy B is supported by the majority. Because $\mathrm{P}$ is a democrat, she must believe that policy B is right. Accordingly, she believes that both policy A and policy B are right. But since the policies are mutually exclusive, this is a paradox.

However, it depends on certain specifications whether this is actually a paradox. For it to be a paradox, $\mathrm{P}$ must think both $\mathrm{A}$ and $\mathrm{B}$ are right literally all things considered. But it is far from obvious that this is what we mean when we vote. Why not think about it as a matter of value pluralism? One value (at least) is the promotion of whatever justice requires, and another is the principled value of democracy, understood as a set of procedures. Obviously, if morality both requires justice and principled democracy, it generates two reasons that might come in conflict. This, however, is so for most, if not all, value pluralisms. For instance, many egalitarians are, and need to be, value pluralists in order to avoid (all things considered)

\footnotetext{
${ }^{19}$ Richard Wollheim, 'A paradox in the theory of democracy', in eds. P. Laslett and W.G. Runciman, Essays in Philosophy, Politics and Society (New York: Barnes \& Noble, 1962), pp. 71-87.
} 
levelling down implications, i.e. to favor an even outcome between e.g. two individuals, say 10, 10 , over an unequal outcome where everyone is better of, say 50,60 . Therefore they claim efficiency to be another value the promotion of which should somehow be balanced with the promotion of equality (and whatever else might be of value). ${ }^{20}$ Similarly, our reason to accept the outcome of a democratic procedure should be balanced with our reason to do what justice requires. Thus, morality may require both (substantial) justice and principled democracy and this need be no more paradoxically than any other form of value pluralism.

\section{Why morality requires principled democracy only if disagreement can change the all things considered right political position}

After this rough sketch of what I take principled democracy to be, I now need to show that there can be principled democracy only if disagreement can change the all things considered right political position. This is in order to finish the first aim of the paper, namely to show that May's suggestion implies that there can be only instrumental reasons for democracy, if any.

So, if morality requires principled democracy, it can either be all it requires or only part of what it requires. In either case it follows that disagreement can change what the all things considered right political position is. To realize that, consider first the case in which principled democracy is all morality requires. Here the right political position is determined only by procedures, and procedures are obviously sensitive to disagreement. If only Ann, Ben, and Clarke are parties in a vote and all believe that $\mathrm{P}$, then $\mathrm{P}$ is right. But if Ben and Clarke, on the other hand, disagree that $\mathrm{P}$, then $\mathrm{P}$ will not be right. Hence, disagreement can change what the (all things considered) right political position is.

20 See e.g. Iwao Hirose, Moral aggregation (Oxford University Press, 2014). 
Second, if principled democracy is required, but not all that is required by morality, then the all things considered right political position is determined by procedures and by (substantial) justice. For instance, if justice requires justice as fairness but the majority disagrees, then, even though the majority is wrong about it, morality requires that the majority has a say in the question of what policies to implement. The all things considered right political position is therefore some balanced position between these two requirements. Hence, disagreement can change the all things considered right political position.

I can therefore finish the first aim of this paper: If morality requires principled democracy, it means that the mere fact of disagreement can change the all things considered right political position. And if the mere fact of disagreement can change the all things considered right political position, then the mere fact of disagreement is a principled moral reason to accept a political position that we otherwise perceive to be morally inferior. The latter (italic) is the antecedent that May rejects. Therefore May's suggestion implies that there can be only instrumental reasons for democracy, if any. This also means that if morality requires principled democracy, then May's antecedent is still standing and there is ample room also for a principled moral reason to compromise.

\section{Why principled democracy?}

The objection that May's suggestion implies that there can be only instrumental reasons for democracy, if any, is, obviously, only interesting if principled democracy is plausible. I therefore want to explain why I think it is. Let us first take a rough look at two existing candidates: 
Jeremy Waldron seems to argue for some form of "principled" democracy. First, and very roughly, because there is disagreement about what the right (political) decisions are some method of decision-making must be used that does not rely on the merits of the decisions. Second, majority rule respects persons as equals. Therefore, one must respect legislation stemming from majority rule under what he calls 'the circumstances of politics', that is under the circumstances of disagreement. ${ }^{21}$ For Waldron, the fact of disagreement and respect therefore ground an intrinsic value of democracy, independently of justice. If Waldron is right, disagreement can change the all things considered right political position.

However, for two reasons I doubt that this is the right justification. First, as May argues, it is not really clear what bridges the gap between respect and compromise ${ }^{22}$, and therefore, it seems similar to me, what really bridges the gap between respect and the intrinsic value of democracy. In order to respect a person it might be sufficient to let her influence the political outcome, but it is much harder to see why you necessarily must let her influence the political outcome before it is fair to say you respect her. After all, it seems easy to imagine cases where respect is satisfied by other means. Second, as Thomas Christiano has argued:

The trouble is that we ought to expect disagreement about the legitimacy of the collective decision procedures themselves in addition to the disagreement that animates the call for those procedures. So the argument from disagreement is self-defeating. ${ }^{23}$

\footnotetext{
${ }^{21}$ Jeremy Waldron, Law and Disagreement (Oxford University Press, 1999), p. 109.

22 May, 'Principled Compromise and the Abortion Controversy', p. 343.

23 Thomas Christiano, 'Waldron on Law and Disagreement', Law and Philosophy 19 (2000), pp. 513-543, p. 520.
} 
(The mere fact of) disagreement cannot explain that we should follow a procedure when we disagree without also explaining that we should follow a procedure when we disagree about what procedure to follow when we disagree. Etc. Accordingly, it cannot literally be the mere fact of disagreement that should do the explanatory work.

Also Thomas Christiano himself argues that "the democratic process has intrinsic fairness". ${ }^{24}$ Contrary to Waldron, however, he does not take democratic fairness to stem from some other moral value, but to be part of justice itself. Thereby he avoids the self-defeating objection. Justice requires public realization of equal advancement of interests, the principle of which “[...] supports democracy as the uniquely best realization of equality under the circumstances of disagreement and fallibility." 25 This also means that: "Democratic directives give contentindependent reasons since one must accept a democratic decision as binding even when one disagrees with it. 26 " If Christiano is right, disagreement can change the all things considered right political position.

According to Christiano, democratic decisions take precedence over other reasons as long as they do not undermine the very value by which they are justified, namely equal advancement of interests. This means that a "democratic" decision to enslave a minority is not a real democratic decision since it undermines the very value that grounds democracy, namely equal advancement of interests. Whereas this is a plausible implication, we ought to remember that equal advancement of interests is compatible with, for instance, any tax level between

\footnotetext{
24 Thomas Christiano, 'The authority of democracy', Journal of Political Philosophy 12.3 (2004), pp. 266-290, p. 269.

25 Thomas Christiano, 'The authority of democracy', Journal of Political Philosophy 12.3 (2004), pp. 266-290, p. 276.

26 Thomas Christiano, 'The authority of democracy', Journal of Political Philosophy 12.3 (2004), pp. 266-290, p. 287.
} 
approx. 0 and approx. 100. Though it seems plausible that we always have a reason to accept a democratic decision that we disagree with, it is much harder to see why that reason always takes precedence over other reasons. If Nozick is right that taxation is slavery, and a democratic decision results in an income tax level at 99,9\% then why should a taxpayer give all moral weight to the latter and non to the former when she decides how to act? Or, if justice requires equality of resources and democratic decisions result in a very high degree of inequality (of resources) then why should a poor starving man give all moral weight to the latter and non to the former when he considers whether to steel a baguette from the richest man in the society?

\section{Principled democracy as the best explanation}

So, if not for the reasons Christiano suggests, why principled democracy? Well, I suggest that regardless of what justice requires, morality also requires that everyone relevantly affected by a decision has a say in the creation of that decision. In fact, I do not think we need any underlying value, such as respect, to justify that. I think we can accept the all affected principle as a fundamental requirement of morality because of the benefits in terms of explanatory power we thereby gain, following a method of hypothetical deduction or inference to the best explanation:

It can namely explain why we, if we take the place of the sovereign king, have a reason to compromise with the people, which I assume satisfy our intuition, and it can explain why Ann on the deserted island has a reason, but perhaps not a decisive reason, to compromise with Ben, which I assume do not contradict our intuition. More generally, it can explain why we often should accept democratic decisions even when they are mistaken according to what we 
believe, or even know, justice requires, say if democratic procedures result in an income tax level at $40 \%$ while justice requires an income tax level at $45 \%$. But it can also explain why we sometimes should not accept democratic decisions, since our reason to accept them should be balanced with our reason(s) to do what justice requires, say if democratic procedures result in persecution of some minority while justice requires (some kind of) equality of opportunity.

Furthermore, principled democracy is needed to make sense of legitimacy as a requirement of morality distinct from moral rightness. In political philosophy (and theory) there are numerous comprehensive discussions about what legitimacy requires where legitimacy (most often) is taken to mean something distinct from moral rightness. In fact, discussions of legitimacy seem exactly to be discussions of how society should proceed when its members disagree about what justice requires. If legitimacy is distinct from moral rightness it implies that our reason not to violate its requirements (whatever they more precisely are) will (at least eventually) be in conflict with our reason to do what justice requires. If disagreement cannot change what the all things considered right position is, requirements of legitimacy and requirements from moral rightness (or justice) are simply contradictory if distinct. Following the nerve in this literature, the requirement of principled democracy might be seen as what legitimacy requires, or as part of what legitimacy requires. Thus, the explanatory power we gain from assuming principled democracy gives us reason to think morality requires principled democracy, and the all affected principle seems to do just fine as the justifying fundamental moral requirement. We need not look for another value, such as respect.

A final detail worth mentioning: When we ground principled democracy on the all affected principle as a fundamental requirement of morality we are insensitive to the self-defeating 
objection. This is so because the all affected principle is no direct requirement of following any procedure. Rather, we should follow $a$ procedure if it satisfies the all affected principle, and if it satisfies the all affected principle there is no reason to believe disagreement about what procedure to follow should be given any independent moral considerations.

\section{4: What does morality require when we disagree?}

I have established that, first, if morality requires principled democracy, then disagreement can change the all things considered right political position. Second, if disagreement can change the all things considered right political position, then principled compromise is possible, in contrast to May's suggestion. I mean to suggest, however, that principled democracy and principled compromise are not only possibilities but effective reasongenerating requirements of morality, and in this final section of the paper I want to elaborate on how I think they relate, since, after all, they are not the same, at least not intuitively speaking. Thereby I hope to shed light on the more general question of what morality requires when we disagree.

A compromise involves two or more agents agreeing on a specific outcome that each of them regards as inferior to their otherwise preferred outcome. ${ }^{27}$ This may be for pragmatic or for principled reason. A democracy, on the other hand, involves two or more agents following certain procedures, such as voting, when they disagree about how their society should be run. This, too, may be for pragmatic or principled reason. Of course, democratic procedures may not always result in outcomes that all of the participating agents perceive to be inferior to

\footnotetext{
${ }^{27}$ According to May's definition of compromise, compromises require reciprocity. Also democracy might require reciprocity, but I leave out that matter for reasons of simplicity. See: Simon C. May, 'Compromise', in eds. H. LaFollette, International Encyclopedia of Ethics (Oxford: Blackwell, 2013), pp. 959-68.
} 
their otherwise preferred outcome. Rather, the resulting outcome may end up being equivalent to some of the agents' otherwise preferred outcome, for instance the otherwise preferred outcome of the majority after a vote. Nonetheless the similarity to compromise is very obvious, and in a sense democracy is a compromise: The agents accept to follow procedures for the very (principled or pragmatic) reason that other agents disagree with them about what the otherwise superior outcome is. Thereby they run the risk, or simply accept, that the outcome of the procedure is inferior to their (otherwise) preferred outcome.

Also in terms of motivation, democracy and compromise are alike. They may both be motivated by pragmatic and/or principled reasons. I take it here that pragmatic reasons includes epistemic reasons of finding out what justice requires, and pragmatic moral reasons such as wishes for peace and wishes for stability. A principled reason for democracy as well as a principled reason for compromise seem to stem from recognition of something like the all affected principle - a fundamental requirement of morality telling us that we all ought to have a say, ceteris paribus, in the creation of decisions that affect us.

I suggest the all affected principle to be the fundamental requirement of morality that grounds both principled democracy and principled compromise. The best way to understand this, I think, is by saying that there is a set of procedures, Px, including compromise, voting, expert delegation, coin flip etc., such that when we disagree about what justice requires, we have a principled moral reason (though not necessarily a decisive reason) to engage in one of the procedures in Px. When there is relevant disagreement we simply have a reason (though not necessarily a decisive reason) to engage in one of the procedures in Px independently of 
"[...] any impediment to other goals it may incidentally generate". This moral requirement applies universally and independently of existing democratic institutions.

To illustrate, in the deserted island case Ben believes it is fair if he and Ann split the fishing gain 50/50, whereas Ann believes it is fair if the first two fish they catch each day are being split 50/50, but anything beyond that 70/30 in her favour. Ann has the power to do as she likes and is faced with two moral reasons, assuming her take on justice is correct: Her (principled) reason to implement the just distribution and her principled reason to follow one of the procedures in Px, because Ben disagrees with her. But which procedure ought she follow?

\section{The right procedure}

I take it that whenever there is relevant disagreement, we have a principled reason to follow the procedure that gives the best satisfaction of the all affected principle. Intuitively, a majority vote combined with some minority protection seems to be a much better satisfaction than, say, a lottery where one person wins all power. Even though a precise understanding of the all affected principle would require a paper of its own (at least), some details are worth specifying here:

First, even if the all affected principle is a fundamental requirement of morality, it does not automatically follow that we should follow any of the procedures I have mentioned, or any procedures at all. Ann may simply adjust her reason to do what is otherwise right for the fact that Ben disagrees with her and thereby determine what is all things considered right without care for Ben's consent to the details. For instance, she may decide that they split the first two 
fish they catch each day 50/50, but anything beyond that 69/31 in her favour. Thereby she gives some adjustment to the fact that Ben disagrees. Similarly, instead of voting we can easily imagine some ideal observer, who knows what the affected individuals actually believe is the otherwise morally right political position. Based on this knowledge and the relevant function as for how to aggregate, she designs all laws and policies. We can also imagine that her job of doing so results in a better satisfaction of the all affected principle than what results from deliberation and voting (expert delegation or what have you). However, it is a fact that such ideal observer does not exist in our world. More well-known democratic procedures must therefore satisfy the all affected principle. But which one?

Well, when we have large numbers, majority vote (combined with some minority protection) seems superior to the alternatives. Compared to a lottery, for instance, majority vote seems to be a much better representation of the citizens aggregated will. And compared to a compromise, majority vote also seems to be a better representation and a much more precise procedure. In fact, it is highly indeterminate what a compromise of one thousand different positions would look like. Majority vote seems to give us the best satisfaction of the all affected principle.

However, often democratic institutions are not present or only few agents are relevantly affected. In such cases, compromise might be the procedure we are left with. But how can we know when a compromise satisfies the all affected principle? Or, as Peter Jones and Ian O'Flynn have asked: How can a compromise can be fair? Obviously, it will require a very precise understanding of the all affected principle to determine whether a compromise is fair at a micro level between two individuals, but as Jones and O'Flynn suggests " [...] there is 
nothing puzzling about subjecting a compromise to a test of pure procedural fairness [...]."28 In line with this suggestion I suggest a compromise to be fair iff it satisfy the all affected principle.

\section{Boundary problems}

The all affected principle must be specified, ideally, such that we for any collective decision can determine if it has been procedurally fair. This also includes the problems often referred to as the boundary problems of democracy. ${ }^{29}$ Who counts as relevantly affected by a decision? And is it disagreement about all kinds of questions that generates a principled moral reason to follow one of the procedures in Px? Or are there restrictions? For instance, if Ben wants to have a say in the question of what dress Ann should wear. For a democracy to be liberal (and plausible), I take it that there must be some such restrictions.

Finally, an open question concerns how to weigh our reason to do what justice requires with our reason to follow one of the procedures in Px, when we disagree about the former. It is beyond the scope of this paper to answer this question in details, but I take it that in cases of sovereignty our reason to follow one of the procedures in Px increases proportionally with the number of relevantly affected individuals, ceteris paribus, such that in the democracy for fun case our reason to follow Px is approximately 5 million times bigger than Ann's reason to follow Px in the deserted island case, where only Ben and herself are present.

\section{Final remarks}

\footnotetext{
${ }^{28}$ Peter Jones and Ian O’Flynn, 'Can a compromise be fair?', Politics, Philosophy \& Economics 12 (2013), pp. 115135, p. 126.

${ }^{29}$ See e.g. Gustav Arrhenius, 'The Boundary Problem in Democratic Theory', in ed. Folke Tersman, Democracy Unbound: Basic Explorations I (Stockholm: Filosofiska institutionen, Stockholms Universitet, 2005), pp. 14-29.
} 
Having made, hopefully, the most important clauses to my suggestion, I want finally to comment on the case May took to illustrate the question of principled compromise, namely whether Jane, a politician, has:

[...] principled reason for moral compromise with the dissenting minority independent of any pragmatic consideration of future political fallout (even if she) were in a position to successfully implement her political position in its entirety say after leading her party to a decisive electoral victory. ${ }^{30}$

The question is, what does my suggestion imply for Jane?

Well, I rejected this case of illustration because it seems plausible that at least some of us think Jane should not compromise exactly because there already has been a vote. I therefore take it that whether Jane has a principled reason to compromise depends on whether Px already has been rightly followed, and I take it that Px has been rightly followed iff the all affected principle has been satisfied. If Jane's electoral victory resulted from democratic procedures that completely satisfy the all affected principle, then I cannot see how Jane could have principled moral reason to compromise with the dissenting minority. Her reason to accommodate the views of the dissenting minority has already been accounted for by following the democratic procedures. A principled compromise with the dissenting minority after having followed the right democratic procedures seems simply to be counting the same reason twice.

30 May, "Principled Compromise and the Abortion Controversy", p. 320-321. 
However, in real life politics it might often be that "democratic procedures" do not properly satisfy the all affected principle. In many real life cases, political agents therefore do have a principled moral reason (though not necessarily a decisive reason) to accept political positions that they believe (or even know) are morally inferior to the otherwise right political position. In lack of better democratic institutional design the best satisfaction of this reason might well be to compromise. ${ }^{31}$

31 Acknowledgement ... 